\title{
The Effectiveness of Self Care Management on Improving the Quality of Life in Chronic Kidney Failure Patients in Internal Medicine Inpatients RSUD Ulin Banjarmasin
}

\author{
Onieqie Ayu Dhea Manto ${ }^{1}$, Devi Agustin ${ }^{2}$, Devi Kharismawati ${ }^{3}$ \\ \{onieqie89@gmail.com ${ }^{1}$, Deviagustin26@gmail.com², Devikharismawati72@gmail.com\} \\ ${ }^{123}$ Medical Surgical, Nursing Program, Faculty of Health Sari Mulia University, Banjarmasin, Indonesia.
}

\begin{abstract}
Chronic kidney failure can also be interpreted as a late-stage kidney disease resulting in progressive and irreversible chronic kidney function disorder, therapy carried out by patients with chronic kidney failure to replace kidney function that is broken one of which is hemodialysis therapy. self care management and quality of life of patients should be an important concern for health professionals, especially nurses because it can be a reference for the success of an action/intervention or therapy. This study's aim is to know the effectiveness of self care management to improve the quality of life in patients with chronic renal failure with hemodialysis in PDP Ulin Hospital Banjarmasin. The method used is quantitative research with descriptive research type. The study design uses a cross-sectional approach. The result in Bivariate analysis results obtained with a value of $\mathrm{p}=0.045<0.05 \mathrm{H}^{\mathrm{a}}$ accepted means that statistically obtained results that there is the effectiveness of self care management to improve quality of life in patients with chronic renal failure with hemodialysis in the PDP inpatient hospital Ulin Banjarmasin.
\end{abstract}

Keyword: self care management, quality of life, chronic kidney failure

\section{INTRODUCTION}

Chronic kidney failure is a worldwide health problem that affects the medical issues, economic and social which was great for patients and their families, both in developed countries and in developing countries [13]. Chronic kidney failure can also be interpreted as a late stage kidney disease resulting in progressive and irreversible chronic kidney function disorder, resulting in decreased body's ability to maintain metabolism and electrolyte fluid balance [8].

World Health Organization (WHO) said the growth in the number of patients with kidney failure in 2013 has increased 50\% from the previous year. In the United States, the incidence and prevalence of kidney failure increased by $50 \%$ in 2014. The prevalence of CKD in Indonesia in 2018 is 3.8\% of Indonesians suffering from chronic kidney failure. In Indonesia, the prevalence of chronic kidney failure is ranked first in North Kalimantan with a percentage of $6.4 \%$ and the last rank in West Sulawesi is $1.8 \%$. Prevalence in men (4.17\%) is higher than women (3.52\%) [10]. Then, in South Kalimantan in 2018 recorded chronic kidney failure as much as $2.7 \%$. This disease is ranked 9th out of the 10 biggest diseases in South Kalimantan Province [4].

Ulin Hospital Banjarmasin is a class A hospital that is designated as the highest referral or as a central hospital in South Kalimantan. The prevalence of patients with chronic kidney failure in Ulin Hospital in Banjarmasin ranks sixth [5]. Based on data from the disease room in Ulin Hospital Banjarmasin, the number of patients with chronic kidney failure from May to July 2019 totaled 138 people consisting of 66 women and 72 men.

Chronic kidney failure is a global health problem with an increased incidence, prevalence and morbidity. Risk factors such as hypertension, diabetes, smoking, use of NSAID analgesic drugs, and the use of energy drinks affect the occurrence of chronic kidney disease [15]. Patients with chronic renal failure with blood urea less than $150 \mathrm{mg} / \mathrm{dl}$, usually without complaints or symptoms. The clinical picture will be evident if the blood urea is more than $200 \mathrm{mg} / \mathrm{dl}$ because the concentration of blood urea is an indicator of the retention of the remnants of protein metabolism in the body. Therapy carried out by patients with chronic kidney failure to replace kidney function that is broken one of which is hemodialysis therapy. Hemodialysis is a kidney replacement therapy for patients with chronic kidney disease. This therapy is carried out to 
replace damaged kidney function [2]. The purpose of hemodialysis is to remove toxic nitrogenous substances from the blood and remove excess water in the body [11].

Quality of life is a broad concept because it is influenced by various things such as physical health, psychological, level of independence, social relations, personal beliefs and the environment [6]. Hemodialysis has quite an impact on the quality of life of patients with chronic kidney failure. [12]. stated that the long process of hemodialysis in patients with chronic kidney failure will cause physical stress, the patient will experience fatigue, headaches, and cold sweat due to decreased blood pressure. Hemodialysis therapy will also affect the psychological state of the patient. Patients will experience disturbances of thought processes and concentration and disturbances in social relations. All of these conditions will cause a decrease in the quality of life of patients with chronic kidney failure undergoing hemodialysis therapy.

Patients with chronic kidney failure who undergo hemodialysis also have a disorder of selfcare fulfillment (self-care deficit). Self care is the performance or practice of individual activities to take the initiative and shape their behavior in maintaining life, health and well-being [5]. Self-care deficit has an impact on the patient's ability to carry out daily activities such as aspects of physical needs which consist of nutrition management, fluid intake regulation, treatment therapy regimen, rest / sleep activity and exercise. Disorders of daily self-care will have an impact on the fulfillment of the patient's daily activities such as eating, drinking, bathing, dressing, dressing up, personal hygiene, toileting and mobility [2].

Orem theory also who says that patients with chronic renal failure undergoing hemodialysis therapy will be able to maintain his health after many know about the disease and the symptoms experienced selfcare management and quality of life of patients should be an important concern for health professionals, especially nurses because it can be a reference for the success of action/intervention or therapy. One of the nurses' tasks is to help patients determine their self-care. Knowing the ability and willingness of patients with chronic kidney failure in relation to self-care management helps and encourages patients to be active in the treatment process and improve the quality and quantity of their lives.

Based on this background, the aim of this study was to know the effectiveness of self-care management in improving the quality of life in patients with chronic kidney failure with hemodialysis at PDP Ulin Hospital in Banjarmasin.

\section{MATERIALS AND METHODS}

The research method used is descriptive research. The study design used a cross-sectional approach. The study population was 72 patients with a sample of 12 patients who experienced chronic kidney failure in May to July 2019. The sampling method using accidental sampling technique. Hypothesis testing uses Fisher's exact test with a significance level of $\alpha=0.05$.

\section{RESULTS}

\section{Characteristics of Responden}

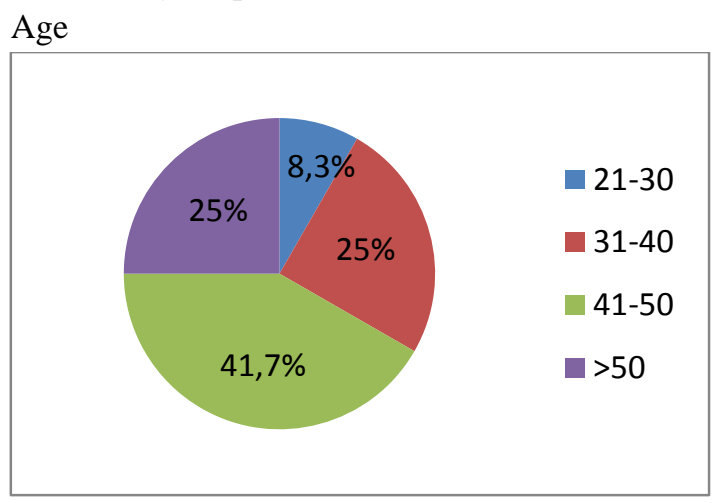

Figure 1 Characteristics by Age

Figure 1 shows that of the 12 respondents, the highest age level was 41-50 years, amounting to 5 people $(41.7 \%)$ and the lowest age was $21-30$ years, amounting to 1 person $(8.3 \%)$. 


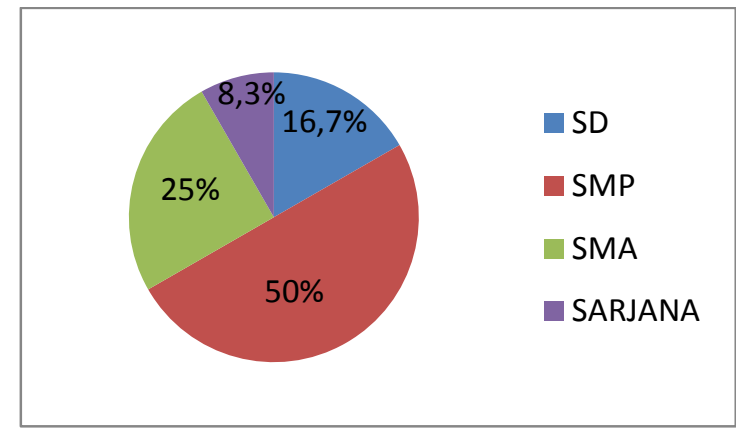

Figure 2 Characteristics Based on Education

Figure 2 shows that out of the 12 respondents, the highest level of education was junior high school with 6 people $(50 \%)$.

Duration of Hemodialysis

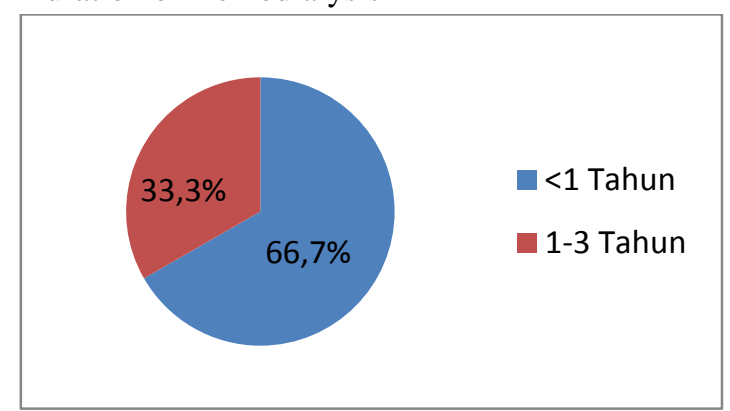

Figure 3 Characteristics Based on the Length of Hemodialysis

Figure 3 shows that of the 12 respondents, the highest length of hemodialysis was <1 year, amounting to 8 respondents $(66,7 \%)$.

\section{Analysis of Univariate}

Self Management Method

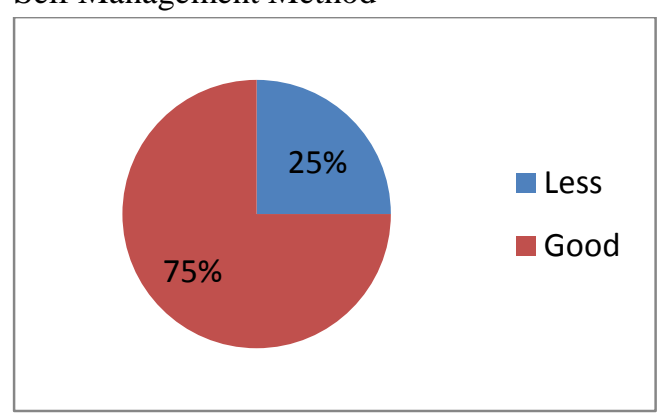

Figure 4 Self Care Management of Chronic Kidney Failure Patients

Figure 4 shows that most of the self care management of chronic failing patients in the Internal Medicine Inpatient Room at Ulin Hospital Banjarmasin with a good category of (75\%) 9 respondents

Quality of life 


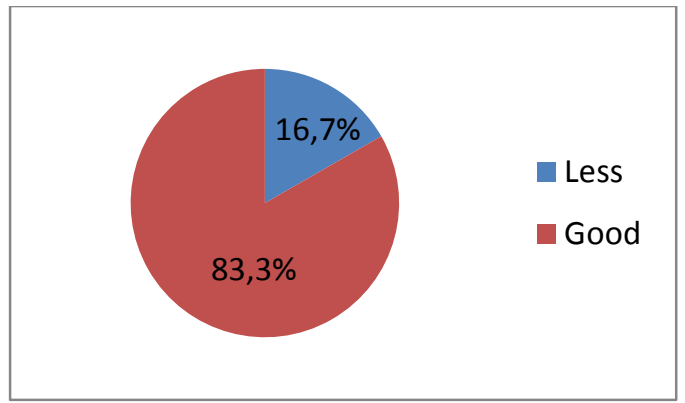

Figure 5 Quality of Life of Chronic Kidney Failure Patients

Figure $5 \mathrm{~m}$ enunjukkan that most of the quality of life of patients with chronic renal failure in the patient wards of Medicine Hospital Ulin Banjarmasin as great with both categories of (83, $3 \%) 10$ respondents.

\section{Analysis of Bivariate}

Table 1 Cross-tabulation of the Effectiveness of Self Care Management on Improving the Quality of Life in Chronic Kidney Failure Patients in the Inpatient Room of PDP Ulin Hospital Banjarmasin.

\begin{tabular}{|c|c|c|c|c|c|c|c|c|}
\hline \multirow{3}{*}{ No. } & \multicolumn{5}{|c|}{ Quality of life } & & \multirow{2}{*}{ tal } & \multirow{2}{*}{$P$ value } \\
\hline & \multirow{2}{*}{$\begin{array}{c}\text { Self Care } \\
\text { Management }\end{array}$} & \multicolumn{2}{|c|}{ Not Good } & \multicolumn{2}{|c|}{ Good } & & & \\
\hline & & $\mathrm{N}$ & $\%$ & $\mathrm{~N}$ & $\%$ & $\mathrm{~N}$ & $\%$ & \multirow{4}{*}{0,045} \\
\hline 1. & Not Good & 2 & 16,7 & 1 & 8,3 & 3 & 25 & \\
\hline 2. & Good & 0 & 0 & 9 & 75 & 9 & 75 & \\
\hline \multicolumn{2}{|r|}{ amount } & 2 & 16,7 & 10 & 83,3 & 12 & 100 & \\
\hline
\end{tabular}

Table 1 shows the hacyl bivariate analysis using test Fisher's Exact Test was obtained $\mathrm{p}=$ 0.045 therefore $\mathrm{P}<0.05$ it is stated that the effectiveness of self-care management to improve the quality of life in patients with chronic renal failure in the patient wards of Medicine Hospital Ulin Banjarmasin

\section{DISCUSSIONS}

Self Care Management of Chronic Kidney Failure Patients

Based on the results of a study of 12 respondents with chronic kidney failure respondent's self-care management data obtained with a good category by 75\%. A study by Riegel, (2012), suggests that self-care is defined as the activity of a person to take the initiative and show with his own awareness to preserve life, a function of health, continue his development and well-being by discovering the need for regulation of his function and development. Aspects according to self-care management include physical aspects consisting of fluid restriction, diet control, medication, and sports activities, psychological aspects and spiritual aspects [11]. In line with research by [10], factors that influence self-care in patients with chronic kidney failure undergoing hemodialysis, namely age, sex, level of education, length of HD, knowledge, motivation and family support. The support system is very important, especially social support or social support from the people closest, in this case, is family [10].

According to Wells and Anderson (2011) said that social support is an important factor and a factor that determines the level of health. Family support in implementing self care management for hemodialysis patients is needed. This is in accordance with research conducted by Dyah, et al (2017) that good family support gives a significant meaning in improving self care management of hemodialysis patients, so that it will help patients achieve better health status with p value $0.01<0,05$. And then, study by Wasis (2008) at the age of 18-65 years that the more a person's age increases, their maturity or maturity will increase technically and psychologically, and will be more able to carry out their duties. Meanwhile, different results were stated by [17] that age> 65 years of physical and psychosocial conditions of patients decreased so that their self-management activities also declined. he results of self-care management research are less $(25 \%) 3$ respondents. Patients rarely check food content, rarely reduce salt and fat intake, rarely reduce sugar intake, 
rarely avoid artificial ingredients (preservatives, chemicals, herbs) and often fill the stomach too full. Whereas, from the aspect of exercise patients rarely practice such as walking, jogging, or running

Fluid control or hemodialysis patients the aim is to maintain adequate fluid status in achieving optimal quality of life. Some other patients have been able to minimize thirst by reducing thirst-inducing foods such as salt, chili, monosodium glutamate (MSG) and limiting daily activities [4]. In line with research by [5], the ability to self care in fluid management in patients with chronic kidney failure undergoing hemodialysis is still not optimal. This is caused by a lack of patient understanding and patient despair about the disease.

\section{Quality of Life for Chronic Kidney Failure Patients}

The Quality of life of respondents with chronic kidney failure was good (83.3\%). Quality of life is an individual's perception of the abilities, limitations, symptoms, and psychosocial nature of his life in the cultural context and value system to carry out his role and function. In terms of spiritual instruments, family and social relationships, most respond to statements such as respondents diligently praying and worshiping, their confidence will make them happy to live and provide strength in dealing with problems. This study is in accordance with [14], that the quality of life of $53.3 \%$ due to environmental, social and family support greatly helps reduce psychological disorders due to chronic kidney failure which is considered a terminal disease so that the quality of life of respondents can improve. In addition, to supporting from the family, environment and social [14]. it also revealed that hemodialysis is a kidney replacement therapy used in patients with acute illness and patients with end-stage kidney disease.

And then, the quality of life results is less (16.7\%). Kaltsouda, et al (2011) coping with stress due to chronic diseases is very influential in changing one's quality of life. Emotional conditions with a defensive or defensive attitude are coping styles that tend to affect the mental and physical components in assessing the quality of life of patients' quality of life, therefore assessing coping and depression in CKD patients must be considered with the aim to improve their mental and physical. In line with the study of [6], that adaptive coping can improve the quality of life of patients with chronic kidney failure undergoing hemodialysis therapy.

\section{The Effectiveness of Self Care Management on Improving the Quality of Life of Chronic Kidney Failure Patients}

Bivariate Fisher Exact Test analysis results obtained $p=0.045$, meaning that there is effectiveness of self-care management in improving the quality of life of chronic kidney failure patients in PDP Hospital, Ulin Hospital, Banjarmasin. In this study, most respondents have good self-care management and quality of life. Based on the results of this study that the higher the self-care management, the higher the quality of life of patients with chronic kidney failure undergoing hemodialysis. In this study, some patients were in severe conditions, for inpatient care for almost all patients besides the diagnosis of chronic kidney failure, there were also all patients entering the inpatient room with chronic kidney failure with complications such as anemia and diabetes.

This is in line with research [1], shown from a significant comparison between the quality of life of patients with chronic kidney failure with comorbid hypertension and diabetes mellitus with a p-value of 0,000 . Changes in kidney function over a long period of time can result in further damage to the nephron. Sclerotic lesions are formed more so that it can cause oblique glomerulus which decreases kidney function and causes a vicious circle that develops slowly. A history of hypertension and a history of diabetes mellitus are associated with chronic kidney failure and the patient will feel discomfort, tightness, edema, chest pain, nausea or even vomiting, and muscle cramps that cause severe pain. The age factor is also closely related to the prognosis of the disease and life expectancy. Those over the age of 55 have a very large tendency to develop various complications that worsen kidney function compared to those under 40 years [1]. The highest age category in this study was $41-50$ years $(41.7 \%) 5$ respondents and> 50 years $(25 \%) 3$ respondents.

In terms of gender characteristics, all respondents were male (12 respondents). Clinically, men have a risk of chronic kidney failure 2 times greater than women. This is possible because women pay more attention to health and maintain a healthy lifestyle than men, so men are more susceptible to chronic kidney failure than women. This study is in line with a study by [12] hat gender variables have a statistically significant relationship between men and women. 


\section{CONCLUSION}

\section{Conclusion}

Characteristics of respondents mostly aged 41-50 years that is as much as 5 respondents (41.7\%), mostly based on education namely junior high school as much as 6 respondents $(50 \%)$, most characteristics of respondents with HD duration $<1$ year with 8 respondents $(66.7 \%)$ and The results of bivariate analysis obtained values with $\mathrm{p}=0.045<0.05 \mathrm{H}^{\mathrm{a}}$ accepted meaning that statistically obtained results that there is the effectiveness of self care management to improve quality of life in patients with chronic renal failure with hemodialysis in PDP inpatients at Ulin Hospital Banjarmasin.

\section{Recomendation}

Patients who are classified as having poor quality are expected to continue to dig up information to improve the quality of life of patients by improving and paying attention to self-care management of patients with chronic kidney failure and should collect information sources such as those from the closest person, books, electronic media or with officers health.

\section{REFFERENCES}

[1] Alfians, et al. Perbandingan kualitas hidup pasien gagal ginjal kronik dengan comorbid faktor diabetes mellitus dan hipertensi di ruangan hemodialisa RSUP Prof Dr. R. D. Kandou Manado. E-Jurnal Keperawatan (e-Kp). 5(2).(2017)

[2] Alligood, MR \& Tomey AN. Nursing Theorist and Their Work, Sixth Edition, St. Louis Mosby. (2014)

[3] Brunner\&Suddart. Buku Ajar Keperawatan Medikal Bedah. Edisi 8 Volume 2.Jakarta: EGC. (2013)

[4] Dinkes. Profil Kesehatan Kalimantan Selatan Tahun 2018. Kalimantan Selatan

[5] Dyah, et al. 2017. Self care management pasien hemodialisa ditinjau dari dukungan keluarga. Jurnal Ilmu Kesehatan. 6(1):109-117. (2018)

[6] Evi, et al. Indikator kualitas hidup pasien gagal ginjal yang menjalani hemodialisa berdasarkan strategi koping. Jurnal Ners Vol. 6 No. 2: 187-191. (2011)

[7] Fauliya Nurmala Arova. Gambaran self care management pasien gagal ginjal kronis dengan hemodialysis di wilayah tangerang selatan tahun 2013. [Skripsi]. Universitas Islam Negeri Syarif Hidayatul Jakarta. (2013)

[8] Faradisa\&Titiek. Gambaran self care status cairan pada pasien hemodialisa. Jurnal Care. Vol. 4. No.2:53-63. (2016).

[9] Nofitri. Gambaran kualitas hidup penduduk dewasa pada lima wilayah di Jakarta. (2009)

[10] Hermawati, et al. 38 Faktor-Faktor yang Mempengaruhi Self Care Diet Nutrisi Pasien Hemodialisa di RSUD DR. Moewardi Surakata. Gaster. Vol XIV (2). (2016)

[11] Rendy, M Clevo dan Margareth TH. Asuhan Keperawatan Medikal Bedah Penyakit Dalam. Yogyakarta : Nuha Medika. (2012)

[12] Restu dan Woro. Faktor risiko gagal ginjal kronik di unit hemodialysis RSUD Wates Kulon Progo. Majalah Farmaseutik. 11 (2): 316-320. (2015)

[13] Kementrian Kesehatan RI; Riset kesehatan dasar tahun 2018. Badan Penelitian dan Pengembangan Kesehatan Kementerian RI tahun 2018. (2018)

[14] Sufiana. Hubungan Lamanya Hemodialisa Dengan Kualitas Hidup Pasien Gagal Ginjal Di RS PKU Muhammadiyaj Yogyakarta. [Skripsi]. Sekolah Tinggi Ilmu Keperawatan Aisiiyah Yogyakarta. (2016)

[15] Supriyadi, Wagiyo, Widowati, \& Ratih, S. Tingkat Kualitas Hidup Pasien Gagal Ginjal Kronik Terapi Hemodialisa. Jurnal kesehatan Masyarakat, Volume 6, No 2. (2011)

[16] Syamsiah, N. Faktor-Faktor yang Berhubungan dengan Kepatuhan Pasien CKD yang Menjalani Hemodialida di RSPAU Dr. Esnawan Antariksa Halim Perdana Kusuma Jakarta. Tesis. Fakultas Ilmu Keperawatan, Universitas Indonesia. (2011)

[17] Tina, et al. Faktor-faktor yang berhubungan dengan manajemen diri pada pasien yang menjalani hemodialysis di ruang hemodialisa RSUP DR Hasan Sadikin Bandung. Jurnal Ilmu Keperawatan. 1(2):162-168. (2013) 
[18] Pranandari R., Supadmi W. Faktor Resiko Gagal Ginjal Kronik di Unit Hemodialisis RSUD Wates Kulon Progo. Majalah Farmaseutik, Vol 11 No. 2. (2015)

[19] WHO. World Health Statistics 2014: World Health Organization 2014. (2014) 